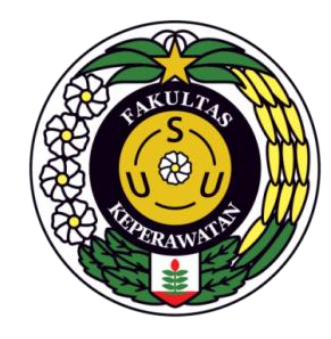

KAJIAN ILMIAH

\title{
PERAN PERAWAT DALAM TINDAKAN REHABILITATIF PASIEN PASCA STROKE DI RUMAH SAKIT
}

\author{
DISUSUN OLEH :
}

\author{
RINI DEBORA SILALAHI (197046015) \\ rinisilalahi19@gmail.com
}

PROGRAM STUDI MAGISTER KEPERAWATAN

FAKULTAS KEPERAWATAN

UNIVERSITAS SUMATERA UTARA

2019 


\title{
PERAN PERAWAT DALAM TINDAKAN REHABILITATIF PASIEN PASCA STROKE DI RUMAH SAKIT
}

\author{
Rini Debora Silalahi \\ Program Studi Magister Keperawatan Fasultas Keperawatan Universitas Sumatera Utara
}

\begin{abstract}
ABSTRAK
Stroke adalah suatu kondisi susunan sistem saraf pusat yang patologis akibat adanya gangguan peredaran darah. Perubahan gaya hidup masyarakat yang serba instan dan praktis mengakibatkan orang semakin malas untuk beraktivitas dan menjalankan pola hidup sehat. Setelah mengalami stroke, $60-70 \%$ penderita mengalami gangguan fungsi motorik atas. Keadaan ini memerlukan rehabilitatif secepatnnya, agar fungsi motorik atas bisa segera pulih. Pemulihan motoris anggota gerak atas dapat terjadi oleh karena pemberian latihan seperti mobilisasi (ROM Pasif) dan rangsangan taktil. Terdapat pengaruh Range Of Motion (ROM) terhadap kekuatan otot dan rentang gerak pasien pasca perawatan stroke. Diperlukan dukungan keluarga dalam pemulihan pasien pasca stroke. Pasien dan keluarga juga perlu mendapat pendidikan kesehatan untuk dapat menerapkan latihan ROM di rumah secara rutin dan berkelanjutan.
\end{abstract}

Kata Kunci : Peran perawat, Rehabilitatif, Rom Pasif

\section{A. Latar Belakang}

Stroke adalah sindrom klinis yang awal timbulnya mendadak, progresif cepat, berupa deficit neurologis fokal, atau global, yang berlangsung 24 jam atau lebih atau langsung menimbulkan kematian, dan semata-mata disebabkan oleh gangguan peredaran darah otak non traumatik (Rendy dan Margareth, 2012). Stroke menimbulkan gejala antara lain : kelumpuhan wajah atau anggota badan, bicara tidak lancar, bicara tidak jelas (pelo), mungkin perubahan kesadaran, gangguan penglihatan, dan lain-lain. Prevalensi stroke di Indonesia berdasarkan diagnosis kesehatan sebesar 7 per mil dan yang terdiagnosis tenaga kesehatan atau gejala sebesar 12,1 per mil (RISKESDAS, 2013).

Stroke merupakan penyebab kematian ketiga tersering di negara maju, setelah penyakit jantung dan kanker. Setiap tahun, hampir 700.000 orang Amerika mengalami stroke dan stroke mengakibatkan hampir 150.000 kematian. 11\% orang Amerika berusia 55-56 mengalami infark serebal silent prevalensinya meningkat sampai $40 \%$ pada usia 80 tahun dan $43 \%$ pada usia 85 tahun (Adrian, 2013). Menurut WHO, setiap tahunnyaa angka kejadian kematian akibat darah tinggi hamper 9,4 juta akibat penyakit jantung dan stroke. Penyakit ini merupakan penyebab kematian nomor satu di dunia. Hipertensi kerap terjadi dengan penyakit lain yakni obesitas, kolestrol, diabetes yang dapat meningkatkan resiko. Sebanyak $76 \%$ kasus hipertensi tidak 
terdiagnosa sejak awal, sehingga menimbulkan keterlambatan penanganan yang dapat mengakibatkan kerusakan organ.

Perawat berperan penting dalam pencegahan dan penanggulangan stroke, baik dari upaya promotif, preventif, kuratif maupun rehabilitatif. Untuk upaya rehabilitatif pada klien stroke, terutama pada klien pasca stroke. Hal ini untuk mencegah stroke berulang, yang dapat memperburuk kondisi klien pasca stroke dan meminimalkan kecacatan. Pasca stroke biasanya klien memerlukan rehabilitasi seperti terapi fisik, terapi wicara, terapi okupasi. Rehabilitasi psikologis juga diperlukan, seperti berbagi rasa, motivasi, terapi wisata, dan sebagainya. Karena pasien pasca stroke biasanya, merasa kondisi tubuh yang cacat membuat penderita merasa tidak berguna dan merasa membebani keluarga (Maulana, 2009).

Latihan Range of Motion (ROM) merupakan salah satu bentuk latihan dalam proses rehabilitasi yang dinilai masih cukup efektif untuk mencegah terjadinya kecacatan pada pasien dengan stroke. Pengamatan yang dilakukan penulis di RS Abdoel Moeloek didapatkan bahwa rehabilitasi pada pasien stroke yang mengalami hemiparesis atau hemiplegia dilakukan oleh fisioterapis selama kurang lebih 15 menit setiap terapi namun evaluasi penilaian terhadap tindakan belum dilakukan secara optimal.

Berdasarkan yang telah diuraikan yaitu semakin meningkatnya penderita stroke dengan berbagai dampak yang ditimbulkan akibat serangan stroke, yaitu kematian ataupun kecacatan maka perawat tertarik untuk mengkaji bagaimana peran perawat dalam tindakan rehabilitatif pasien pasca stroke.

\section{B. Tujuan}

Tujuan kajian ini adalah untuk melihat bagaimana peran perawat dalam tindakan rehabilitatif pasien pasca stroke.

\section{Metode}

Kajian ini dilakukan dengan mencari sumber data baik dari jurnal maupun buku-buku yang berhubungan dengan peran perawat dalam tindakan rehabilitatif pasien pasca stroke. Artikel penelitian yang digunakan bersumber dari Repository USU, Google Scholar. Penelusuran dilakukan dengan kata kunci sesuai dengan topik yaitu perawat, tindakan rehabilitative, pasca stroke. 


\section{Hasil}

Perawat telah melakukan tindakan terapi didepan keluarga agar keluarga mengetahui tujuan terapi dan mengetahui cara melakukannya. Dalam penelitian terjadi peningkatan skor ARA Test setelah dilakukan terapi. Hari pertama skor ARA Test adalah 0, hari kedua meningkat menjadi 5, hari ketiga meningkat menjadi 17, dan hari keempat meningkat menjadi 25. Meskipun skor ARA Test belum meningkat sepenuhnya (Nilai Normal adalah 57), namun dari hari kehari terjadi peningkatan skor ARA Test. Hari pemberian terapi yang cukup singkat juga dapat mempengaruhi hasil yang didapat, dimana implementasi hanya dilakukan selama 4 hari. Dalam penelitian yang dilakukan oleh Susanto (2016) menyatakan terapi ini dilakukan selama 6 minggu untuk mendapatkan hasil yang signifikan dalam peningkatan skor ARA Test.

Pemulihan pasien pasca stroke tidak sepenuhnya dapat dilakukan oleh perawat karena jika pasien sudah diperbolehkan pulang maka keluarga turut serta berkontribusi dalam rawatan dirumah. Oleh Karena itu perlu dilakukan pendekatan family centered. Pendekatan family centered nursing dalam discharge planning ini bertujuan agar dapat menyiapkan keluarga untuk memenuhi kebutuhan fisik, kognitif, dan emosional pasien stroke.

\section{E. Pembahasan}

Beberapa tujuan mobilisasi Range Of Motion (ROM) yaitu mempertahankan atau memelihara fleksibilitas dan kekuatan otot, memelihara mobilitas persendian dan mencegah kelainan bentuk, kekakuan dan kontraktur. Nilai kekuatan otot dan rentang gerak yang meningkat tersebut juga memberi jawaban pada manfaat Range Of Motion (ROM) yaitu memperbaiki tonus otot, meningkatkan mobilisasi sendi, dan memperbaiki toleransi otot untuk latihan. Latihan Range of Motion (ROM) merupakan salah satu bentuk latihan dalam proses rehabilitasi yang dinilai masih cukup efektif untuk mencegah terjadinya kecacatan pada pasien dengan stroke.

Latihan mobilisasi pasif dilakukan dengan menggerakkan semua sendi pada anggota gerak yang lumpuh, sampai terjadi range of motion 39 (ROM) secara penuh. Latihan ROM pasif dapat dilakukan oleh perawat, fisioterapis atau keluarga pasien. Tindakan selanjutnya yaitu melakukan aktivitas elevasi dengan cara meninggikan letak kepala secara bertahap untuk 
kemudian dicapai posisi setengah duduk dan pada akhirnya posisi duduk. Apabila pasien sudah dapat duduk secara aktif, maka latihan berdiri dan berjalan dapat dimulai. Selain itu pasien mulai diperkenalkan program Activity of Daily Living/ADL. Dalam arti sempit, ADL dapat diartikan sebagai bebas melakukan kegiatan kehidupan sehari - hari tanpa bantuan pihak lain.

Penelitian yang dilakukan oleh (Rimmer JH. et all, 2009) tentang A Preliminary Study to Examine the Effects of Aerobic and Therapeutic (Nonaerobic) Exercise on Cardiorespiratory Fitness and Coronary Risk Reduction in Stroke Survivors. Mendapatkan hasil bahwa terdapat perbedaan antara gerakan aerobic dan nonaerobic pada penurunan resiko reduksi jantung pada apsien stroke.

Pada penelitian lain yang terkait dengan intervensi pada stroke kronis menegaskan bahwa pemulihan fungsional dan perubahan otak dapat terjadi lebih dari 6 bulan setelah stroke, bahkan dari hasil penelitian menunjukkan bahwa pemulihan fungsional akibat stroke dapat terus berlangsung selama beberapa bulan sampai tahunan (Susanto, 2016). Dalam melakukan implementasi inovasi ini, terdapat beberapa hambatan. Hambatan dalam melakukan implementasi ini adalah, klien harus dalam keadaan sadar penuh (Composmentis), mengerti arahan dan perintah, serta mampu diajak untuk berkomunikasi.

Masalah keperawatan yang timbul pada pasien kelolaan dapat diatasi bila terjadi kolaborasi yang baik antara pasien dan pemberi pelayanan kesehatan, dalam hal ini khususnya perawat. Pasien memiliki peranan penting untuk melakukan perawatan mandiri (self care) dalam perbaikan kesehatan dan mencegah rawat ulang dirumah sakit (Barnason, Zimmerman \& Young, 2011).

Tindakan rehabilitatif pada pasien pasca stroke tidak sepenuhnya dapat dilakukan oleh perawat. Namun dibutuhkan kolaborasi antara keluarga dan perawat. Keluarga harus tahu, mengenai masalah serta terapi yang didapat oleh klien, agar dapat melanjutkan perawatan dirumah. Keluarga juga menjadi salah satu bagian penting dalam pemulihan pasien pascastroke. Selain itu, keluarga juga bisa menjadi jembatan agar klien bisa lebih patuh pada program pengobatan, terapi, dan latihan agar pemulihan klien bisa lebih optimal meski sudah keluar dari RS. Selain itu, keluarga juga berperan untuk menjaga pola hidup klien selama dirumah, agar serangan stroke kedua tidak terjadi. 


\section{F. Penutup}

Pemulihan pasien pasca stroke dapat dilakukan dengan tidakan rehabilitative ROM pasif yang dilakukan oleh perawat dan tidak terlepas dengan adanya dukungan keluarga (family centered). 


\section{Daftar Pustaka}

Bakara, D. M dan Warsito. (2016). Latihan Rom terhadap rentang Sendi Pasien Pasca Stroke. Diaksese dari http://schoolar.google.co.id/scholar/journalrompascastroke.

Chaidir, Reny dan Zuardi, I.M. (2014). Pengaruh Latihan ROM dengan Bola Karet Terhadap Kekuatan Otot Pasien Stroke non Hemoragi di RSSN Bukit Tinggi. http://schoolar.google.co.id/scholar/rehabilitasikeperawatanpascastroke.

Dewi, Triana. (2017). Peran Perawat Profesional Untuk Pasien-Mutu Pelayanan Kesehatan. Journal Keperawatan. Diakses dari http://mutupelayanankesehatan.net.

Festy, P. (2012). Peran Keluarga dalam Pelaksanaan Rehabilitasi Medik pada Pasien Stroke. Journal Keperawatan. http://schoolar.google.co.id/scholarrehabilitasipascastroke.

Lingga, Lenny. (2013). All About Stroke. Jakarta: Elex Media Komputindo.

McEachen, Irene dan Koegh, Jim. (2018). Manajemen Keperawatan Demystified. Yogyakarta: Penerbit Andi.

Mertha, Ade Laksmi. (2013). Pengaruh Terapi Latihan terhadap Kemandirian Melakukan Aktivitas Kehidupan Sehari-hari Pasien Stroke Iskemik. Diakses dari http://schoolar.google.co.id/scholar/jurnal+askep+pasca+stroke.

Nursalam. (2016). Manajemen Keperawatan. Jakarta: Penerbit Salemba Medika.

Pudiastuti, R.D. (2017). Penyakit Pemicu Stroke. Yogyakarta: Nuha Medika.

R, Sofwan. (2013). Stroke dan Rehabilitasi Pasca Stroke. Jakarta: Bhuana Ilmu Populer.

Simamora, R. H. (2013). Upaya Pembinaan Perawat Di Rumah Sakit Ngesti Waluyo Parakan Temanggung Jawa Tengan. Journal Keperawatan, 8(2).

Sundah B.M, dkk. (2014). Pengetahuan Masyarakat Mengenai Penanganan Rehabilitasi Medik Pada Penderita Stroke. http://schoolar.google.co.id/scholar/journal54++pascastrokeD\%.

Supriadi, Henni. (2015). Pengembangan Pelayanan Medik dan Keperawatan Di Rumah Sakit. Diakses dari:http://pustaka.unpad.ac.id.

Wirawan, R.P. (2009). Rehabilitasi Stroke pada Pelayanan Kesehatan Primer. Majalah Kedokteran Indonesia. Diakses dari http://schoolar.google.co.id/ journalpascastroke. 